\begin{tabular}{|c|c|}
\hline Title & Highly efficient induction of triploid Pacific abal one Haliotis discus hannai by caffeine treatment \\
\hline Author(s) & $\begin{array}{l}\text { Okumura, Sei-ichi; A rai, Katsutoshi; Harigay a, Y oshitaka; Eguchi, Hirotaka; Sakai, Mizuho; Senbokuya, Hiroaki; } \\
\text { Furukawa, Suehiro; Y amamori, Kunio }\end{array}$ \\
\hline Citation & $\begin{array}{l}\text { Fisheries Science, } 73(2), 237-243 \\
\text { https://doi.org/10.1111/.1444 2906.2007.01329.x }\end{array}$ \\
\hline Issue Date & 2007 \\
\hline Doc URL & http:/hdl.handle.net/2115/35215 \\
\hline Rights & ○ 2007 公益社団法人日本水産学会; @ 2007 The Japanese Society of Fisheries Science \\
\hline Type & article \\
\hline File Information & arai-117.pdf \\
\hline
\end{tabular}

Instructions for use 


\title{
Highly efficient induction of triploid Pacific abalone Haliotis discus hannai by caffeine treatment
}

\author{
Sei-Ichi OKUMURA, ${ }^{1 *}$ Katsutoshi ARAI, ${ }^{2}$ Yoshitaka HARIGAYA, ${ }^{1}$ Hirotaka EGUCHI, ${ }^{1}$ Mizuho \\ SAKAI, ${ }^{1}$ HiROAKI SENBOKUYA, ${ }^{1}$ SUEHIRO FURUKAWA ${ }^{3}$ AND KunIo YAMAMORI ${ }^{1}$ \\ ${ }^{1}$ School of Fisheries Sciences, Kitasato University, Sanriku, Ofunato, Iwate 022-0101, ${ }^{2}$ Laboratory \\ of Breeding Science, Graduate School of Fisheries Sciences, Hokkaido University, Hakodate, \\ Hokkaido 041-8611, and ${ }^{3}$ The Marine Development Co. Ltd, Sanriku, Ofunato, Iwate 022-0211, \\ Japan
}

\begin{abstract}
In order to develop a highly efficient method for mass production of triploid Pacific abalone Haliotis discus hannai, caffeine treatment that is safe and inexpensive was optimized. To suppress the first meiotic division, fertilized eggs were exposed to either a 10- or $15-\mathrm{mM}$ caffeine solution for $24 \mathrm{~min}$ beginning at $12 \mathrm{~min}$ after fertilization. In most treated batches, the rates of cleaved eggs showed no significant difference from the control batches. However, in most treated batches, the rates of occurrence of normal larvae and the survival rates of the early juveniles were significantly lower than those of the controls. The triploid rates at 6 days to 11 months after settlement in all the treated batches were extremely high (91-100\%). There was no significant difference in the mean triploid rates between 10 - and $15-\mathrm{mM}$ caffeine treatments. These results suggest that both treatment conditions were conducive to triploid abalone production. One live $2 n / 3 n$ mosaic specimen was found in the treated batches. However, since the frequency of mosaic was extremely low, the mosaicism would probably not have an adverse effect on the stable production of triploid abalones.
\end{abstract}

\section{KEY WORDS: archaeogastropoda, caffeine, flow cytometry, Haliotis discus hannai, inverte-} brate, mollusca, mosaic, triploid.

\section{INTRODUCTION}

The abalone, which is an economically important marine product in Japan, China, Australia, New Zealand, and some other countries, has been studied to use triploidy for aquaculture, because superior growth of induced.triploid abalones has been expected. ${ }^{1-4}$ For the mass production of triploid abalone in commercial hatcheries, large quantities of eggs must be treated simply, cheaply, and safely because the treatment must not damage either humans or the natural environment. Cold ${ }^{1,5-7}$ and hot $^{5}$ treatments for triploid induction are safe because no chemicals are used. However, these treatments require an optimal treatment temperature to be maintained in a large volume of sea water in order to treat a large quantity of eggs, and expensive large-scale equipment

\footnotetext{
*Corresponding author: Tel: 81-192-44-1905. Fax: 81-192-44-1905. Email: okumura@kitasato-u.ac.jp Received 23 June 2006. Accepted 10 October 2006.
}

to control water temperature is needed. Pressure treatment $t^{5}$ is also considered safe, but specific equipment, a French press, is required and it is usually difficult to treat many eggs on a commercial scale because the pressure cell has limited volume. Chemical treatments such as cytochalasin $B(C B)^{1,4,8,9}$ and 6-dimethylaminopurine (6-DMAP) $)^{2,4,10-12}$ are simpler than physical treatments because specific equipment is not required. However, CB is highly toxic, and careful handling is necessary. Moreover, both CB and 6-DMAP are very expensive and not realistic for large scale treatment in commercial hatcheries.

Caffeine treatment combined with temperature shock has shown successful triploid induction in some bivalves ${ }^{13-15}$ and abalone. ${ }^{16}$ Caffeine, a chemical that is a recognized food constituent in many countries, is safer and cheaper than either CB or 6-DMAP. Therefore, caffeine is a promising agent for the mass production of triploids. However, if caffeine treatment requires combination with temperature shock for the mass production of triploids, a large-scale temperature control system is 
still necessary. Triploid induction by caffeine treatment only is more useful, but it has been reported exclusively in bivalves by Scarpa et al. ${ }^{17}$ However, the rate of triploid induction was lower than that by CB treatment performed at the same time.

In our previous studies, ${ }^{18,19}$ caffeine treatment without combined temperature treatment was effective for the induction of triploid abalone. However, these studies were inconclusive because the resulting triploid rates were estimated in mixed samples comprising many larval individuals before settlement. In order to verify the efficacy of caffeine treatment for the induction of abalone triploids, triploid rates at the juvenile stage after settlement should be estimated based on the ploidy examination of each individual. In the present study, as an extension of our previous work, ${ }^{18,19}$ we report that induction of triploid Pacific abalone Haliotis discus hannai by caffeine-only treatment is highly efficient.

\section{MATERIALS AND METHODS}

\section{Triploid induction and larval rearing}

Pacific abalone egg and sperm specimens were obtained from $12^{-}$mating groups by artificial spawning ${ }^{20}$ in the hatchery of the Marine Development Co., Iwate, Japan. Then, 635 000-4 880000 fertilized eggs from each mating group were divided into control and treatment batches and maintained in filtered sea water $\left(20 \pm 0.5^{\circ} \mathrm{C}\right)$. Fertilized eggs of the experimental batches were collected $^{5}$ and treated with sea water containing either 10 or $15 \mathrm{mM}$ caffeine to suppress the first meiotic division ${ }^{18,19}$ as follows. These mating experiments for triploid induction were performed in 2001 (mating nos. 101, 102, .. 100+n) and 2002 (mating nos. 201, 202, .. 200 + n). In the treated batches, the eggs from mating nos. 117, $118,119,120,121,201,202,204,209,212,217$, and 219 were exposed to the caffeine solution for $24 \mathrm{~min}$ beginning at $12 \mathrm{~min}$ after fertilization at $20 \pm 0.5^{\circ} \mathrm{C} .{ }^{19}$ The control batches had no caffeine treatment. Detailed data of the treatment conditions in each treated batch are shown in Table 1. After treatment, the control and caffeine-treated eggs were transferred to a $20-\mathrm{L}$ plastic tank and rinsed five or six times with $20 \pm 0.5^{\circ} \mathrm{C}$ filtered sea water to remove excessive spermatozoa and chemicals. These eggs were then incubated at $20 \pm 1^{\circ} \mathrm{C}$. Two hours after fertilization, the rates of cleaved eggs in control and treated batches were estimated. ${ }^{18,19}$ From 18 to $20 \mathrm{~h}$ after fertilization, the hatched larvae were collected and transferred to a different 20 -L plastic tank to separate them from undeveloped eggs, which sank to the tank bottom. These collected larvae were reared at $20 \pm 1^{\circ} \mathrm{C}$ in an incubation room; the rearing sea water was changed twice per day until settlement (three days after fertilization). On day 3 after fertilization, the larvae from each batch were collected and the proportion of normal larvae was estimated. ${ }^{19}$

\section{Larvae settlement and juvenile rearing}

In 2001, for the purpose of larval settlement, all surviving larvae in each treated batch derived from mating nos. $117,118,119,120,121$, and the control batches derived from mating no. 121 were either left unmixed or mixed with larvae from other treated batches (Table 1). The larvae were then released into 1 -t tanks $\left(20 \pm 1^{\circ} \mathrm{C}\right)$ that contained 180 microalgal-colonized settlement plates (vinyl chloride, $330 \mathrm{~mm} \times 330 \mathrm{~mm}$ ). After settlement, the juveniles were reared at a temperature of $17-21^{\circ} \mathrm{C}$ in accordance with standard methods of abalone culture. In order to determine the ploidy status, between 8 and 11 months after settlement, samples of epipodial tentacle tissue were collected $^{21}$ from juveniles of the treated and control batches (settlement groups A, B, C, and D, Tables 1 and 2) for biopsy analysis using flow cytometry (see next section).

In 2002, three days after fertilization, the larvae from mating nos. 201, 202, 204, 209, 212, 217, and 219 in treated and control batches were collected and released separately into 20 -L plastic tanks containing 16 microalgal-colonized settlement plates (vinyl chloride, $330 \times 160 \mathrm{~mm}$ ) (Table 1). At six days after settlement, the early juveniles from the control and treatment batches that adhered to the settlement plates were counted. At 6-22 days after settlement, the early juveniles of the treated. batches derived from mating nos. 201, 202, 204, $209,212,217,219$, and the control batches derived from mating nos. 201, 202, 204, 217, and 219 were analyzed by flow cytometry to determine ploidy status using the whole body of individuals.

\section{Flow cytometry}

For the early juveniles of the 2002 mating experiments, fresh or Carnoy-fixed individuals were placed into $1.5-\mathrm{mL}$ microcentrifuge tubes and macerated using an ultrasonic generator (Handy Sonic, Tomy Seiko, Tokyo, Japan) for a few seconds with two or three drops of A solution (CyStain DNA 2 step extraction buffer, Partec, Munster, Germany). ${ }^{22,23}$ This solution containing the macerated 
Table 1 Mating and treatment data for triploid induction, and rates of cleaved eggs and normal larvae and settlement data

\begin{tabular}{|c|c|c|c|c|c|c|c|}
\hline $\begin{array}{l}\text { Mating } \\
\text { group }\end{array}$ & Batch & $\begin{array}{c}\text { Caffeine } \\
\text { concentration, mM }\end{array}$ & $\begin{array}{c}\text { Cleaved } \\
\text { eggs, \% }(n)^{\dagger}\end{array}$ & $\begin{array}{c}\text { Normal } \\
\text { larvae, }{ }^{\ddagger} \%(n)^{\dagger}\end{array}$ & $\begin{array}{l}\text { No. of normal larvae } \\
\text { for settlement }\end{array}$ & $\begin{array}{l}\text { Groups after } \\
\text { settlement }\end{array}$ & $\begin{array}{c}\text { Survival of juveniles } \\
6 \text { days after settlement } \\
\%^{\S}(n)^{\dagger}\end{array}$ \\
\hline \multirow[t]{2}{*}{117} & Control & - & $94.0(84)$ & $100.0(9)$ & - & - & - \\
\hline & Treated & 15 & 96.0 (175) & 93.3 (15) & $\begin{array}{c}105000 \\
-\end{array}$ & $\begin{array}{l}\text { A } \\
-\end{array}$ & - \\
\hline \multirow[t]{2}{*}{118} & Control & - & $93.0(100)$ & $96.4(28)$ & - & - & - \\
\hline & Treated & 10 & $93.4(122)$ & $65.8^{*}(38)$ & $\begin{array}{c}375000 \\
-\end{array}$ & $\begin{array}{l}\mathrm{B} \\
-\end{array}$ & - \\
\hline \multirow[t]{2}{*}{119} & Control & - & $95.1(82)$ & $100.0(31)$ & - & - & - \\
\hline & Treated & 15 & 89.6 (106) & $75.0^{*}(24)$ & $\begin{array}{c}135000 \\
-\end{array}$ & $\begin{array}{l}\text { A } \\
-\end{array}$ & - \\
\hline \multirow[t]{2}{*}{120} & Control & - & $91.5(47)$ & 100.0 & - & - & - \\
\hline & Treated & 15 & $81.1(90)$ & $40.0^{* *}$ & $\begin{array}{c}15000 \\
-\end{array}$ & $\begin{array}{l}\mathrm{A} \\
-\end{array}$ & - \\
\hline \multirow[t]{2}{*}{121} & Control & - & $93.2(88)$ & $94.4(18)$ & 255000 & $\mathrm{C}$ & - \\
\hline & Treated & 10 & 94.1 (118) & $87.1(31)$ & 405000 & $\mathrm{D}$ & - \\
\hline \multirow[t]{2}{*}{201} & Control & - & $70.2(47)$ & $95.5(22)$ & 32000 & - & $31.5(9872)$ \\
\hline & Treated & 10 & 77.5 (138) & 82.1 (67) & 29000 & - & $8.9^{* *}(2592)$ \\
\hline \multirow[t]{2}{*}{202} & Control & - & $100.0(36)$ & $100.0(26)$ & 4000 & - & $63.2(2528)$ \\
\hline & Treated & 15 & $93.5(93)$ & $53.8^{* *}(13)$ & 4000 & - & $4.1^{* *}(164)$ \\
\hline \multirow[t]{2}{*}{204} & Control & - & 73.0 (37) & $97.8(45)$ & 25000 & - & $9.6(2392)$ \\
\hline & Treated & 10 & $87.8^{*}(90)$ & 93.9 (49) & 24000 & - & $3.2^{* *}(760)$ \\
\hline \multirow[t]{2}{*}{209} & Control & - & $90.9(165)$ & $91.0(144)$ & 20000 & - & $1.0(192)$ \\
\hline & Treated & 10 & 89.0 (374) & $46.1^{* *}(141)$ & 20000 & - & $0.6^{* *}(112)$ \\
\hline \multirow[t]{2}{*}{212} & Control & - & $89.5(76)$ & $94.4(143)$ & 20000 & - & 9.8 (1968) \\
\hline & Treated & 10 & 92.4 (185) & $30.5^{* *}(95)$ & 20000 & - & $5.1^{* *}(1024)$ \\
\hline \multirow[t]{2}{*}{217} & Control & - & $83.9(31)$ & $100.0(40)$ & 20000 & - & 31.7 (6344) \\
\hline & Treated & 10 & $92.2(103)$ & $70.1^{* *}(137)$ & 20000 & - & $3.7^{* *}(747)$ \\
\hline \multirow[t]{2}{*}{219} & Control & - & $100.0(8)$ & $100.0(21)$ & 20000 & - & 16.1 (3216) \\
\hline & Treated & 10 & $76.9(121)$ & $82.8^{*}(145)$ & 20000 & - & $5.3^{* *}(1056)$ \\
\hline
\end{tabular}

${ }^{*} P<0.05 ;{ }^{* *} P<0.001$, significant differences in Student's $t$-test between control and treated batches within each mating group.

${ }^{\dagger}$ Numbers in parentheses denote sample size.

*Three days after fertilization.

\$Survival rate from larvae ${ }^{\ddagger}$ to settled juvenile. 
Table 2 Triploid rates in treated and control batches

\begin{tabular}{|c|c|c|c|c|c|c|c|}
\hline \multirow{2}{*}{$\begin{array}{l}\text { Settlement group } \\
\text { or mating number }\end{array}$} & \multirow{2}{*}{$\begin{array}{c}\text { Caffeine } \\
\text { concentration (mM) }\end{array}$} & \multirow{2}{*}{$\begin{array}{l}\text { Tissues }{ }^{\S} \text { used } \\
\text { for } \mathrm{FCM}^{\uparrow}\end{array}$} & \multirow{2}{*}{$\begin{array}{c}\text { Age of post-settlement } \\
\text { specimens when } \\
\text { analyzed }\end{array}$} & \multicolumn{4}{|c|}{ No. of specimen identified } \\
\hline & & & & Diploid & Triploid & 2n/3n Mosaic & Triploid rates, \% \\
\hline A & 15 & et & 8-11 months & 0 & 73 & 0 & 100 \\
\hline B & 10 & et & 8-11 months & 6 & 59 & 0 & 91 \\
\hline$C^{\ddagger}$ & - & et & 8 months & 5 & 0 & 0 & 0 \\
\hline $\mathrm{D}$ & 10 & et & 8-11 months & 1 & 49 & 0 & 98 \\
\hline 201-control & - & whole & 12-22 days & 12 & 0 & 0 & 0 \\
\hline 201-treated & 10 & whole & 12-22 days & 0 & 59 & 0 & 100 \\
\hline 202-control & - & whole & 12 days & 4 & 0 & 0 & 0 \\
\hline 202-treated & 15 & whole & 12 days & 0 & 24 & 0 & 100 \\
\hline 204-control & - & whole & 12 days & 4 & 0 & 0 & 0 \\
\hline 204-treated & 10 & whole & 12 days & 0 & 35 & 0 & 100 \\
\hline 209-treated & 10 & whole & 6 days & 1 & 17 & 0 & 94 \\
\hline 212-treated & 10 & whole & 6 days & 0 & 30 & 0 & 100 \\
\hline 217-control & - & whole & 6 days & 4 & 0 & 0 & 0 \\
\hline 217-treated & 10 & whole & 6 days & 0 & 35 & 1 & 97 \\
\hline 219-control & - & whole & 6 days & 5 & 0 & 0 & 0 \\
\hline \multirow[t]{2}{*}{ 219-treated } & 10 & whole & 6 days & 0 & 42 & 0 & 100 \\
\hline & & & & \multicolumn{4}{|c|}{$\begin{array}{l}\text { Mean of } 10 \mathrm{mM} \text { batches: } 97.5 \pm 3.2^{\dagger \dagger} \\
\text { Mean of } 15 \mathrm{mM} \text { batches: } 100.0 \pm 0.0^{\dagger \dagger}\end{array}$} \\
\hline
\end{tabular}

${ }^{\dagger}$ Groups after settlement (see Table 1).

Untreated control batches of D (see Table 1).

set, epipodial tentacle tissue; whole, whole body of individual.

"Flow cytometry analysis.

${ }^{\dagger+}$ Standard deviation. 
cells was filtered into individual $3.5-\mathrm{mL}$ plastic tubes (Partec) using a $50-\mu \mathrm{m}$ mesh sheet (CellTrics filter, Partec). The B solution (CyStain DNA 2 step staining solution, Partec) containing 4',6diamidino-2-phenylindole (DAPI) was then added to a final volume that was three times that of the filtered solution. The resulting solution was used for flow cytometry (Ploidy Analyzer, Partec) analysis according to the manufacturer's instructions. For the juveniles of the 2001 mating experiments, three to five pieces of epipodial tentacle were collected..$^{21}$ The tissues were agitated using a needle with A solution and, thereafter, treated for flow cytometry using the method described above. The mode of fluorescence intensity in the histograms obtained by flow cytometry analysis was compared with that of diploid specimens, which enabled the ploidy status to be determined. ${ }^{23}$

\section{RESULTS}

Rates of cleaved eggs in the control and caffeinetreated batches for each mating group are shown in Table 1. Under 10- and 15-mM caffeine treatment conditions, the rates of cleaved eggs in most mating groups showed no significant differences between the control and treated batches within the same mating group. Rates of occurrence of morphologically normal larvae in most treated batches with either the 10 - or $15-\mathrm{mM}$ caffeine treatment were significantly lower than for the counterpart control batches, as shown in Table 1. In the seven treated batches derived from the 2002 mating experiment, survival rates from the larval stage to the early juvenile stage six days after settlement were significantly lower than for the counterpart control batches (Table 1).

Table 2 summarizes triploid rates obtained in this study. All treated groups in the 2001 mating experiments and the early juveniles in the 2002 mating experiments showed high triploid rates (91-100\%). The one live $2 \mathrm{n} / 3 \mathrm{n}$ mosaic specimen, which had both diploid and triploid cells in the same individual, was identified using the whole body of the individuals (mating no. 217, caffeinetreated) (Table 2, Fig. 1).

\section{DISCUSSION}

In most treated batches, the frequency of morphologically normal larvae and the survival rate of individuals from the larval stage to the early juvenile stage six days after settlement were significantly lower than those measured in the counterpart controls. These results suggest that the

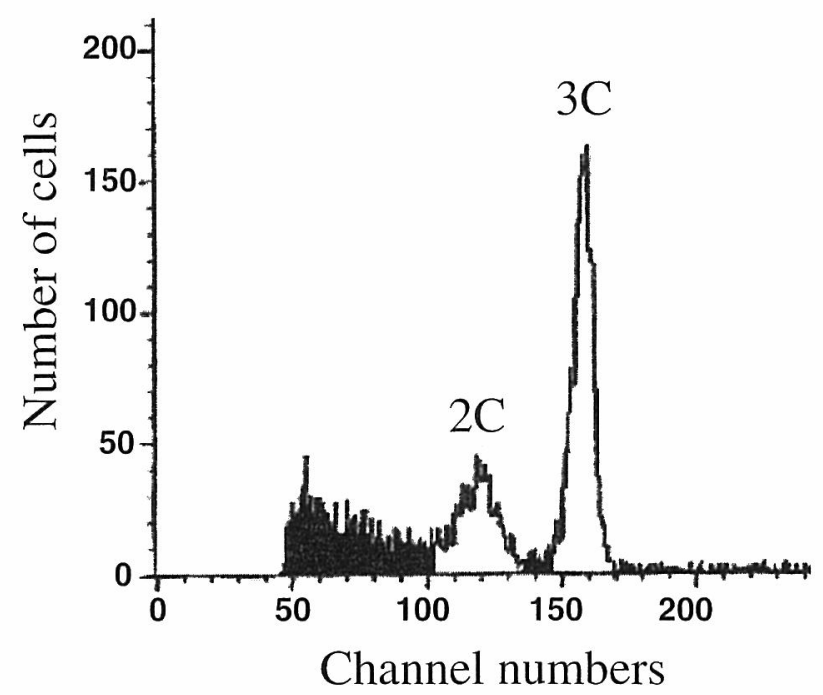

Fig. 1 Flow cytometry analysis histogram of the DNA content in the $2 \mathrm{n} / 3 \mathrm{n}$ mosaic specimen from mating no. 217 caffeine-treated batch six days after settlement. 2C, diploidy and $3 \mathrm{C}$ triploidy.

present caffeine treatment should influence development and resulting survival. Such low larval normality or viability is generally observed when other physical and chemical treatments are applied to induce abalone triploidy. ${ }^{4,5,8,9}$ Thus, the side-effects of the treatment on larval normality and survival are not specific to caffeine.

In this study, however, high triploid rates were observed in all the post-settlement early juveniles and juveniles of the treated groups. Because there was no significant difference in the mean rates between the 10- and 15-mM caffeine treatments (Table 2), we concluded that both conditions are conducive to induce triploids in $H$. discus hannai. Since the high triploid rates were confirmed not in larvae but in the early juveniles and the 8-11 month-old juveniles, the present treatment conditions are optimal to the mass production of triploid abalone. In this study, since caffeine treatment without temperature shock adequately induced triploids and did not annihilate the individuals, high triploid rates were achieved even 11 months after the individuals reached the settlement stage. As described previously, caffeine treatment is simple, safe, and inexpensive. Therefore, this method can be applied for commercial production of triploid abalones in aquaculture. In the near future, aquaculture performance of triploid abalone induced by caffeine treatment should be examined and characterized for commercial use.

In the present study, we found a single living $2 \mathrm{n} / 3 \mathrm{n}$ mosaic specimen in the treated group. Since the frequency of mosaic occurrence was extremely 
low, the mosaicism has no adverse affect on the stable production of triploid abalone. Similar living heteroploid mosaic animals derived from polyploid inductions ${ }^{24,25}$ and normal or natural crossings $^{26-28}$ have been reported in fishes. The present study was the first to report the discovery of a living heteroploid mosaic among chromosomally manipulated abalone. The mechanism and origin of such mosaicism should be clarified in chromosomally manipulated abalone.

\section{ACKNOWLEDGMENTS}

The authors are grateful to Mr. K. Furukawa and T. Ishibashi of the Marine Development Co. for generously donating research materials, and to Dr. N. Horie of Irago Institute Co., Miss H. Shimaya, Miss M. Tsunaki, Mrs H. Tsuruta, Mr. T. Nagahara, Mr. M. Norimatsu, Mr. M. Osawa, Mr. K. Sekiguchi, Mr. Y. Hagiwara, Mr. H. Warashina, Mr. N. Ii, Miss K. Onuma, Miss K. Tamura, and Miss A. Murao of the School of Fisheries Sciences, Kitasato University for expert technical assistance. This study was supported in part by a Grant-in-Aid for scientific research (B) from the Japan Society for the Promotion of Science (JSPS) to KA (No. 13460079).

\section{REFERENCES}

1. Sun Z, Song Z, Li N, Zhao Y, Guan X. A preliminary study on the growth of triploid abalone (Haliotis discus hannai Ino). Transact. Oceanol. Limnol. 1992; 4: 70-75.

2. Yan Z, Chen J. Seed breeding and culturing of triploid abalone Haliotis diversicolor aquatilis. J. Fish. China 2002; 26: 54-60 (in Chinese).

3. Chen Q, Yang J, Gao A, Hu X, Zhao K, Zhao J. A study on the growth comparisons of triploid of Haliotis discus Reeve. Donghai Mar. Sci. 2002; 20: 49-54 (in Chinese).

4. Liu W, Heasman M, Simpson R. Induction and evaluation of triploidy in the Australian blacklip abalone, Haliotis rubra: a preliminary study. Aquaculture 2004; 233: 79-92.

5. Arai K, Naito F, Fujino K. Triploidization of the Pacific abalone with temperature and pressure treatments. Nippon Suisan Gakkaishi 1986; 52: 417-422.

6. Kudo M, Arai K, Fujino K. Triploidization of Haliotis diversicolor diversicolor by cold shock. Nippon Suisan Gakkaishi 1991; 57: 1263-1267.

7. Yang H-S, Ting Y-Y, Chen H-C. Effect of cold shock on the production of triploid zygotes and the embryonic development of small abalone, Haliotis diversicolor supertexta Lischke. Acta Zool. Taiwan 1997; 8: 67-78.

8. Stepto NK, Cook PA. Induction of triploidy in the South African abalone using cytochalasin B. Aquacult. Int. 1998; 6: 161-169.

9. Maldonado R, Ibarra AM, Ramirez JL, Avila S, Vazquez JE, Badillo LM. Induction of triploidy in Pacific red abalone (Haliotis rufescens). J. Shellfish Res. 2001; 20: 1071-1075.
10. Zhang G, Wang Z, Chang Y, Song J, Ding J, Wang Y, Wang R. Triploid induction in Pacific abalone Haliotis discus hannai Ino by 6-dimethylaminopurine and the performance of triploid juveniles. J. Shellfish Res. 1998; 17: 783-788.

11. Yan Z, Chen J, Wu P, Gao X. Triploid of the abalone Haliotis diversicolor supertexta induced with 6-DMAP: by blocking the second polar body of the zygotes. J. Oceanogr. Taiwan Strait 2001; 20: 15-19 (in Chinese).

12. Norris BJ, Preston NP. Triploid induction in the tropical abalone, Haliotis asinine (Linne), with 6-dimethylaminopurine. Aquacult. Res. 2003; 34: 261-264.

13. Yamamoto S, Sugawara $Y$, Nomura T. Chemical and thermal control of triploid production in Pacific oysters and mussels, with regard to controlling meiotic maturation. Adv. Invert. Reprod. 1990; 5: 455-460.

14. Durand P, Wada KT, Komaru A. Triploidy induction by caffeine-heat shock treatments in the Japanese pearl oyster Pinctada fucata martensii. Nippon Suisan Gakkaishi 1990; 56: 1423-1425.

15. Zhang G, Chang Y, Song J, Ding D, Shen J, Wang Y. Triploidy induction in Pacific oyster Crassostrea gigas. Chin. J. Oceanol. Limnol. 1998; 16: 249-255.

16. Mao LJ, Wang ZC, Liu XQ, Li YJ, Gao YM. Induction of polyploid in the Pacific abalone by caffeine-heat shock treatments. Yi Chuan Xue Bao 2000; 27: 959-965 (in Chinese).

17. Scarpa J, Jorge ET, Wada KT. Direct comparison of six methods to induce triploid in bivalves. Aquaculture 1994; 119: 119-133.

18. Okumura S, Furukawa S, Sugie T, Sekimiya D, Toda A, Yamamori K. Triploid larvae of Pacific abalone, Haliotis discus hannai (Archaeogastropoda: Haliotidae) induced by suppression of meiotic division using caffeine treatment. Chromosome Inf. Serv. 1996; 61: 10-12.

19. Okumura S, Furukawa S, Sasaki T, Shimaoka M, Horikawa C, Yamamori K. Suppression of both 1st and 2nd meiotic divisions by caffeine treatment for the production of tetraploid Pacific abalone, Haliotis discus hannai (Archaeogastropoda: Haliotidae). Chromosome Sci. 1998; 2: 123-127.

20. Kikuchi S, Uki N. Technical study on artificial spawning of abalone, genus Haliotis II: effect of irradiated sea water with ultraviolet rays on inducing to spawn. Bull. Tohoku Reg. Fish. Res. Lab. 1974; 33: 79-86.

21. Okumura S. A biopsy method for obtaining chromosome preparation from epipodial tentacle tissue of the Pacific abalone. Nippon Suisan Gakkaishi 1991; 57: 2337.

22. Okumura S, Eguchi H, Harigaya Y, Nakaoka K, Furukawa S, Yamamori K. Cell number in diploid and triploid veliger larvae of Pacific abalone Haliotis discus hannai. Fish. Genet. Breed. Sci. 2002; 32: 103-107.

23. Eguchi H, Okumura S, Arai K, Sakai M, Nagahara T, Norimatsu M, Furukawa S, Yamamori K. Pretreatment method for flow cytometry of larval and early juvenile Pacific abalone Haliotis discus hannai using the ultrasonic generator. Fish. Genet. Breed. Sci. 2003; 33: 35-39.

24. Yamaki M, Satou M, Satou H, Kon Y, Zhang Q, Uchimura Y. Induction of tetraploid amago salmon by hydrostatic pressure and heat shocks and its verification by the maximum number of nucleoli and DNA contents. Fish. Genet. Breed. Sci. 1997; 25: 37-48.

25. Yamaki M, Satou H, Taniura K, Arai K. Progeny of the diploid-tetraploid mosaic amago salmon. Nippon Suisan Gakkaishi 1999; 65: 1084-1089. 
26. Yamaki M, Kawakami K, Taniura K, Arai K. Live haploiddiploid mosaic charr Salvelinus leucomaenis. Fish. Sci. 1999; 65: 736-741.

27. Yamaha E, Murakami M, Takeyama S, Morishima K, Otani S, Horie S, Tanaka M, Fujimoto T, Ohshima K, Sakao S, Aida T, Arai K. Polyploid and mosaic crucian carp found in
Tokotan-numa swamp, Akkeshi, Hokkaido. Fish. Genet. Breed. Sci. 2002; 32: 19-26.

28. Yamaki M, Yamaguchi S, Arai K. Mottled coloration of haploid-diploid and diploid-triploid mosaic amago salmon Oncorhynchus masou ishikawae. Fish. Sci. 2006; 72 : 157-165. 